\title{
Effect of European Seabass (Dicentrarchus Labrax) Fry Source (Wild, NIOF and GAFRD K21) on its Growth Performance and Physiology
}

\author{
A. M. Salem*, N. M. El-Bermawi**, N. R Abdelsalam ${ }^{* * *}$ and M. S. Abokadah ${ }^{* * *}$ \\ *Fish Physiology Lab., Fisheries Division, National Institute of Oceanography \\ \& Fisheries (NIOF), Alexandria, ${ }^{* *}$ Animal and Fish Production Department and \\ *** Agricultural Botany Department, Faculty of Agriculture (Saba Basha) Alexandria \\ University, Alexandria, Egypt.
}

\begin{abstract}
$\mathbf{T}$ HE present study aimed to evaluate the impacts of different sources on the European seabass (D. labrax) fry growth and physiology. One thousand and five hundreds fry from 3 sources were transferred to the lab., the 1st fry group was collected from the wild habitat in El- Meadya region, El- Behira Gov. from the wild fry capture fisheries. The 2nd fry group was $94(\mathrm{dph})$ day post hatching produced in the Marine NIOF Hatchery, El- Anfoushy from induced spawning and the 3rd group fry was $94 \mathrm{dph}$ produced in the Marine GAFRD Hatchery from induced spawning. Fry samples were randomly collected to statistically determine the length, weight growth and physiology performances. The comparative effects of European seabass (D. labrax) fry sources (wild and two hatcheries) and their impacts on length and weight growth parameters, total length, standard length, body width, total weight, gutted weight, hepatosomatic and vesrosomatic indexes. The wild collected fry achieved the best significant $(\mathrm{P}<0.05)$ results in all this growth parameters while the NIOF marine hatchery produced fry achieved the best significant $(\mathrm{P}<0.05)$ results in all these physiology parameters. In conclusion, this study explained why fish farmers prefer wild collected European seabass (D. labrax) fry than hatchery produced fry. Egypt marine hatcheries need more efforts and technology transfer to help marine aquaculture and fisheries development, that need ranching and restocking with hatchery produced fry.
\end{abstract}

Keywords: Dicentrarchus labrax, , fry, wild, hatchery, growth, hepatosomatic and vesrosomatic indexes.

\section{Introduction}

Egypt is the tenth world aquaculture producer and also the first Mediterranean Sea, Arab and African aquaculture producer [1]. Egypt marine aquaculture still depending on fry collected from natural resources (95.437 million fry, only 0.797 million fry of them recorded as Seabreams and Seabass fry). Although Egypt had 6 hatcheries producing 8.906 million fry, only 3.500 million were Seabass fry in 2015 [2]. Not enough or misbalanced or low quality live feeds and microdiets affecting negatively marine hatcheries larval productivity and quality [3, 4]. In 2013, Egypt mass mortalities in Kafr El-Sheik and El- Behira governorates tilapia fish farms which diagnosed as A. hydrophilla outbreak and also, in Maryut Valley, Alexandria governorate in European seabass, gilthead seabream and meagre farms with different reasons as high temperatures and low oxygen stress in seabass and meagre, 100 tons equals 7 million L. E. losses [5] and because of Vibrio sp. outbreak in gilthead seabream after seabass and seabream wild collected fry were transported to these farms [5]. Therefore, the aim of the study were to evaluate the impacts of different resources on the European seabass $(D$. labrax) fry growth and physiology.

Global fish production from capture and aquaculture supplied about 167.2 million tons in 2014, with 73.8 million tons from aquaculture (47.1 from inland and 26.7 million tons from marine aquaculture), providing an apparent per capita supply of $20.1 \mathrm{~kg}$ [1]. China is the world leading aquaculture producer and had produced $58.16 \%$ of the world aquaculture production. FAO [1] reported that in 2014, the composition of world aquaculture production was: freshwater fishes (49.9 million tons), molluscs (16.1 million tons) and crustaceans ( 6.9 million tons). The number of species recorded in FAO aquaculture production 
statistics increased to 580 species and/or species groups farmed around the world, including those once farmed in the past, had been registered with production data by FAO. These species items include 362 finfishes (including hybrids), 104 molluscs, 62 crustaceans, 6 frogs and reptiles, 9 aquatic invertebrates, and 37 aquatic plants [1]. Turkey is the major producer of European seabass (Dicentrarchus labrax), Greece dominates the production of gilthead seabream (Sparus aurata), while Egypt is the main producer of mullets (Mugilidae spp) in the Mediterranean [6].

\section{Materials and Methods}

Experimental fish, duration and location

The present study was conducted using one thousand and five hundreds fry from 3 sources and transferred to the Fish Reproduction and Spawning Lab., the $1^{\text {st }}$ group were 500 hundreds fry collected from the wild habitat in El-Maadyia region, El- Behira Governorate from local fry trader in the seabass fry collecting season from the wild fry capture fisheries., the $2^{\text {nd }}$ group were 500 hundreds of $94 \mathrm{dph}$ fry produced in the Marine General Authority for Fish Resources Development (GAFRD) Hatchery, Km 21 Abou Talat, Alexandria, Egypt from induced spawning of $1600 \mathrm{gm}$ female and $1000 \mathrm{gm}$ male broodstock managed and three generations selected in the hatchery and the $3^{\text {rd }}$ group were 500 hundreds of 94 (dph) day post hatching fry produced in the Marine NIOF Hatchery, El- Anfoushy, Alexandria from induced spawning of $1250 \mathrm{gm}$ female and 600 gm male broodstock collected from Maryut valley fish farm twelve ripe fish of European seabass broodstock. Fry samples collected during the spawning season of 2014/2015 from the wild and both hatcheries.

Induced spawning using hormonal manipulation of the hatchery produced fry

In both hatcheries, Induced spawning were done using luteinizing releasing hormone analogue (LHRHa) and human chronic*gonadotropin hormone (HCG). After broodstock acclimatization, resting and feeding then checked for ripeness. Ripe females injected in the abdominal cavity using two doses, the priming dose were $10 \mu \mathrm{g} \mathrm{LHRHa} \mathrm{kg}{ }^{-1}$ and the second dose were $200 \mathrm{IU} \mathrm{HCG} \mathrm{kg}{ }^{-1}$ releasing dose. Ripe males were injected using the releasing dose only using $200 \mathrm{IU}$ HCG kg-1. The post larvae rearing protocol was almost the same in both hatcheries as shown by Salem [12, 3] and Hebalah [13].

\section{Growth criterias}

Growth of post larvae were measured carefully as total length were to nearest $0.1 \mathrm{~mm}$ and total weight to nearest $0.001 \mathrm{mg}$ to calculate total weight gain, average daily gain, specific growth rate in weight were according to Castell [14], Condition factor were according to Yildiz et al. [15] and average daily gain or increase in length were according to Garber [16] and specific growth rate in length were according to Nour [17].

Weight growth parameters

Total weight gain (WG g/fish)

Total Weight Gain $(\mathrm{WG})=\mathrm{Wt}-\mathrm{W} 0$

Where: W0: the initial fish weight at the start of the experiment.

Wt: the final fish weight at the end of the experiment.

Weight average daily gain (WADG $\mathrm{mg} /$ day)

$\mathrm{ADG}(\mathrm{mg})=\mathrm{Wt}-\mathrm{W} 0 / \mathrm{n}$

Where: W0: the initial fish weight at the start of the experiment.

Wt: the final fish weight at the end of the experiment.

$\mathrm{n}$ : the duration period of the experiment in days.

Weight specific growth rate in weight (WSGR\%)

$\mathrm{SGR}=($ Lin Wt - Lin W0) $100 / \mathrm{n}$

Where: Lin: the natural logarithm.

Weight gain \% (WG\%)

Weight Gain \%=WG/ W0 x 100

Length growth parameters

Total length gain ( $L G \mathrm{~cm} / \mathrm{fish})$

Total length gain $(\mathrm{LG})=\mathrm{Lt}-\mathrm{L} 0$

Where: L0: the initial fish length at the start of the experiment.

Lt: the final fish length at the end of the experiment.

Length average daily gain ( $L A D G \mathrm{~mm} /$ day)

LADG $(\mathrm{mm})=\mathrm{Lt}-\mathrm{L} 0 / \mathrm{n}$

Where: L0: the initial fish length at the start of the experiment.

Lt: the final fish length at the end of the experiment.

$\mathrm{n}$ : the duration period of the experiment in days.

Length specific growth rate \% (LSGR \%)

LSGR \% $=($ Lin FL - Lin IL) $100 / \mathrm{n}$

Where: Lin: the natural logarithm.

IL: the initial fish length at the start of the experiment.

FL: the final fish length at the end of the experiment. 
Length gain \% (LG\%)

Length Gain \% = LG/ L0 x 100

Physiology parameters

Condition factor $(K)$

$\mathrm{K}=\left([\mathrm{Wt}(\mathrm{gm})] /[\mathrm{L}(\mathrm{cm})]^{3} \times 100\right)$

Where: Wt: the total body weight.

L: the total body length.

Hepatosomatic index (HSI)

HSI $=100 \times($ liver weight $(\mathrm{gm}) \times$ body weight $\left.(\mathrm{gm})^{-1}\right)$

Viscerosomatic index (VSI)

VSI $=100 \times($ carcass weight $(\mathrm{gm}) \times$ body weight $\left.(g)^{-1}\right)$

\section{Measurement of water quality}

Water quality measurements were done using AquaReed ${ }^{\circledR}$ Water quality portable electric device were done in water quality and the elctrolid device was gentely putted in the bootom of the experimental tanks away from the airstone and water quality mesurments are Dissolved Oxygen $\%$ (DO \%), pH, Conductivity and Total Dissolved Solids (TDS) while Salinity as part per thousand (ppt) were measured using the referectometer.

\section{Counting the bacterial groups}

Microbiological measurements were done in randomly collected rotifer enrichment environment water samples in the water source and algal source for greenwater for Colony Forming unit (CFU) of Vibrio and Bacillus were done in the Microbiology Lab., Marine Environment Division, NIOF., Serial dilutions from $10^{-2}$ through $10^{-6}$ were made using filtered sterilized sea water. A portion $(0.1 \mathrm{ml})$ from each appropriately diluted sample was used to inoculate plates prepared with seawater agar for total bacterial counting. Bacillus plates were incubated at $30^{\circ} \mathrm{C}$ for $72 \mathrm{~h}$ and Vibrio plates were incubated at $38^{\circ} \mathrm{C}$ for $72 \mathrm{~h}$. Plates of two selective media were inoculated with $1 \mathrm{ml}$ of appropriately dilution sample for counting the different bacterial groups: Vibrio and Bacillus bacterial counts.

\section{Chemicals and media}

All chemicals used for biochemical tests and extraction of antimicrobial activity were of pure grade and purchased from Sigma chemicals, USA. Ingredients of media were all of analytical grade and obtained from recognized chemical suppliers (mainly Oxoid Co.). Media used throughout the work are described below. The composition is given in $\mathrm{gl}^{-1}$. The $\mathrm{pH}$ value of the media was adjusted to 7.5 prior to sterilization. Autoclaving was occurred at $121^{\circ} \mathrm{C}$ for $15 \mathrm{~min}$.
Media used for isolation and enumeration of the different bacterial groups Sea water agar

A selective medium by [18] used for determining Bacillus count bacteria. Peptone, 5 , ferric phosphate, 0.1 , agar, 15 , sea water $1 \mathrm{~L}$.

Thiosulfate citrate bile salt sucrose agar (TCBS)

A selective medium by [19] used for isolating Vibrio spp.: Yeast extract, 5, peptone, 10 , sodium thiosulfate, 10 , sod-citrate, $10, \mathrm{Ox}$ bile, 8 , sucrose, 20 , sodium chloride, 10 , ferric chloride, 1, Bromothymol blue, 0.04, thymol blue, 0.04 and agar, 14 .

\section{Statistical analysis}

Statistical analysis were performed using analysis of variance (ANOVA), differences among means were considered significant at $p$ $<0.05$ multiple range of post hoc comparisons were performed using Duncan's multiple range test and critical ranges to resolve the differences among the means of replication according to Duncan [20] using basic statistics, STATISTICA $^{\circledR}$ software for Windows [21].

\section{$\underline{\text { Results and Discussion }}$}

The effects of European seabass (D. labrax) fry sources (wild and two hatcheries) on length and weight growth parameters, total length, standard length, body width, total weight and gutted weight in gm (Table 1.). The wild collected fry achieved the best significant ( $\mathrm{P}$ $<0.05)$ results in all this growth parameters. Morphometric relationship between length and weight (LWR) is of great importance in fish biology assessments. According to Lagler [22], Length-weight relationship leads itself to comparison of individuals within and between different populations. LWR can be used to assess the well-being of individuals and to determine the possible differences between separate unit stocks of the same species [23, 24].

The European seabass (D. labrax) fry sources (wild and two hatcheries) impacts on length growth performance parameters, total length, length gain, average daily gain in $\mathrm{mm}$, specific growth rate in $\%$ /day and length gain $\%$ growth parameters (Table 2.). The wild collected fry achieved the best significant $(\mathrm{P}<0.05)$ results in 
all this length growth performance parameters. Salem and Ahmed [12], Salem et al. [3], Salem [5], recorded that results of larvae length gains showed that better significantly results achieved by GMW+MP and GMW+S than GMW in most larvae body length and length gains parameters of $7 \mathrm{dph}, 14 \mathrm{dph}, 21 \mathrm{dph}, 25 \mathrm{dph}, 35 \mathrm{dph}$ and $40 \mathrm{dph}$, showed potential application of them in these critical stages and these may be due to many factors and mechanisms such as positive effects of these treatments as supported by Ariğ [25] who showed enhanced growth of gilthead seabream larvae using Bacillus sp. bacteria enriched rotifers and artemia.

The comparative effects of European seabass (D. labrax) fry sources (wild and two hatcheries) on weight growth performance parameters, total weight, weight gain in gm, average daily gain in $\mathrm{mg}$, specific growth rate in percentage/ day and weight gain \% growth parameters (Table 2.). The wild collected fry achieved the best significant $(\mathrm{P}<0.05)$ results in all these weight growth performance parameters. Salem $[12,3]$ recorded that larvae body weight better results achieved by GMW+MP and $\mathrm{GMW}+\mathrm{S}$ than GMW, El-Dakar [26] studied various inclusion levels of a feed additive that contains probiotic bacteria, digestive enzymes and prebiotic spices to evaluate the effect on siganid survival, growth, feed conversion, nutrient utilization, body composition and economics and showed that rabbitfish offered the control diet exhibited lower growth and feed utilization than all experimental treatments. There was no effect of probiotic inclusion level on survival but growth was better at all inclusion levels than in the control. No significant differences in growth were observed among fish groups fed various levels of the probiotic.

TABLE 1. Length, weight, condition factors, hepatosomatic and vesrosomatic indexes of wild collected and hatcheries produced European seabass (D. labrax) fry.

\begin{tabular}{|c|c|c|c|}
\hline Treatments & Wild & GAFRD K21 & NIOF \\
\hline \multirow{2}{*}{ TL (cm) } & $7.320^{\mathrm{a}}$ & $3.760^{\mathrm{b}}$ & $3.260^{\mathrm{b}}$ \\
\hline & \pm 0.657 & \pm 0.152 & \pm 0.207 \\
\hline \multirow{2}{*}{ STL (cm) } & $6.240^{\mathrm{a}}$ & $3.220^{\mathrm{b}}$ & $2.680^{c}$ \\
\hline & \pm 0.639 & \pm 0.110 & \pm 0.148 \\
\hline \multirow{2}{*}{ BW (cm) } & $1.380^{\mathrm{a}}$ & $0.560^{\mathrm{b}}$ & $0.580^{\mathrm{b}}$ \\
\hline & \pm 0.148 & \pm 0.055 & \pm 0.045 \\
\hline \multirow{2}{*}{ TW (gm) } & $4.048^{\mathrm{a}}$ & $0.483^{b}$ & $0.399^{\mathrm{b}}$ \\
\hline & \pm 1.090 & \pm 0.030 & \pm 0.067 \\
\hline \multirow{2}{*}{ GW (gm) } & $3.386^{\mathrm{a}}$ & $0.355^{\mathrm{b}}$ & $0.246^{\mathrm{b}}$ \\
\hline & \pm 0.919 & \pm 0.030 & \pm 0.046 \\
\hline \multirow{2}{*}{ KTL } & $1.013^{\mathrm{ab}}$ & $0.910^{\mathrm{b}}$ & $1.155^{\mathrm{a}}$ \\
\hline & \pm 0.034 & \pm 0.063 & \pm 0.188 \\
\hline \multirow{2}{*}{ KSTL } & $1.650^{\mathrm{b}}$ & $1.449^{\mathrm{b}}$ & $2.068^{\mathrm{a}}$ \\
\hline & \pm 0.227 & \pm 0.112 & \pm 0.258 \\
\hline \multirow{2}{*}{ HSI } & $1.168^{\mathrm{c}}$ & $1.610^{\mathrm{b}}$ & $1.932^{\mathrm{a}}$ \\
\hline & \pm 0.215 & \pm 0.202 & \pm 0.182 \\
\hline \multirow{2}{*}{ VSI } & $7.308^{b}$ & $7.533^{b}$ & $18.673^{\mathrm{a}}$ \\
\hline & \pm 1.462 & \pm 0.226 & \pm 0.822 \\
\hline
\end{tabular}

Values in the same row with different letters are significantly different at $\mathrm{P}=0.05$.

TL: Total length, STL: Standard length, BW: Body width, TW: Total weight, GW: Gutted weight, Condition factor (K) $=\left([\mathrm{Wt}(\mathrm{g})] /[\mathrm{L}(\mathrm{cm})]^{3} \times 100\right)$ Where Wt: the total body weight $(\mathrm{gm})$ and $\mathrm{L}$ : the total body length $(\mathrm{cm})$, Hepatosomatic index $(\mathrm{HSI})=100 \times\left(\right.$ liver weight $(\mathrm{g}) \times$ body weight $\left.(\mathrm{g})^{-1}\right)$, Viscerosomatic index $(\mathrm{VSI})=100 \times($ carcass weight $(\mathrm{g}) \times$ body weight $\left.(\mathrm{g})^{-1}\right)$.

Egypt. J. Vet. Sci. Vol. 49, No.1 (2018) 
TABLE 2. Growth performances of wild collected and hatcheries produced European seabass (D. labrax) fry.

\begin{tabular}{cccc}
\hline Treatments & Wild & GAFRD K21 & NIOF \\
\hline TL (mm) & $73.200^{\mathrm{a}}$ & $37.600^{\mathrm{b}}$ & $32.600^{\mathrm{b}}$ \\
& \pm 6.573 & \pm 1.517 & \pm 2.074 \\
TLG (mm) & $69.400^{\mathrm{a}}$ & $33.800^{\mathrm{b}}$ & $29.200^{\mathrm{b}}$ \\
& \pm 6.573 & \pm 1.517 & \pm 2.074 \\
TLADG (mm) & $0.780^{\mathrm{a}}$ & $0.380^{\mathrm{b}}$ & $0.328^{\mathrm{b}}$ \\
& \pm 0.074 & \pm 0.017 & \pm 0.023 \\
TLSGR (\%/d) & $2.067^{\mathrm{a}}$ & $1.717^{\mathrm{b}}$ & $1.646^{\mathrm{c}}$ \\
& \pm 0.046 & \pm 0.022 & \pm 0.034 \\
TLG\% (\%) & $6940.00^{\mathrm{a}}$ & $3380.00^{\mathrm{b}}$ & $2920.00^{\mathrm{c}}$ \\
TW (gm) & \pm 657.27 & \pm 151.66 & \pm 207.36 \\
\hline WG (gm) & $4.048^{\mathrm{a}}$ & $0.483^{\mathrm{b}}$ & $0.399^{\mathrm{b}}$ \\
& \pm 1.090 & \pm 0.030 & \pm 0.067 \\
WADG (mg) & $4.045^{\mathrm{a}}$ & $0.480^{\mathrm{b}}$ & $0.396^{\mathrm{b}}$ \\
\hline WSGR (\%/d) & \pm 1.090 & \pm 0.030 & \pm 0.067 \\
& $45.445^{\mathrm{a}}$ & $5.389^{\mathrm{b}}$ & $4.454^{\mathrm{b}}$ \\
\hline & \pm 12.244 & \pm 0.335 & \pm 0.757 \\
\hline & $0.668^{\mathrm{a}}$ & $-0.359^{\mathrm{b}}$ & $-0.458^{\mathrm{b}}$ \\
& \pm 0.130 & \pm 0.032 & \pm 0.091 \\
\hline & $404.460^{\mathrm{a}}$ & $47.960^{\mathrm{b}}$ & \pm 6.734 \\
\hline
\end{tabular}

Values in the same row with different letters are significantly different at $\mathrm{P}=0.05$.

TL: Total length, TW: Total weight, Length gain $(\mathrm{LG})=\mathrm{Lf}-\mathrm{Li}$, where $\mathrm{Li}$ and $\mathrm{Lf}$ are initial and final lengths(mm), Length average daily gain $(\mathrm{LADG})=\mathrm{Lf}-\mathrm{Li} / \mathrm{t}$, where $\mathrm{Li}$ and $\mathrm{Lf}$ are initial and final lengths $(\mathrm{mm})$ and $\mathrm{t}$ is the time of experiment (days), Length specific growth rate \% $(\mathrm{LSGR})=(\mathrm{Lin} \mathrm{Lf}-\mathrm{Lin} \mathrm{Li}) 100 / \mathrm{t}$, where $\mathrm{Li}$ and $\mathrm{Lf}$ are initial and final lengths $(\mathrm{mm})$ and $t$ is the time of experiment (days), Length gain $\%(\mathrm{LG} \%)=\mathrm{LG} / \mathrm{Li} \times 100$, where $\mathrm{Li}$ is initial length and LG is Length gain $(\mathrm{mm})$, Total weight gain $(\mathrm{WG})=\mathrm{Wf}-\mathrm{Wi}$, where Wi and $\mathrm{Wf}$ are initial and final weights $(\mathrm{g})$, Weight average daily gain $(\mathrm{WADG})=\mathrm{Wf}-\mathrm{Wi} / \mathrm{t}$, where $\mathrm{Wi}$ and $\mathrm{Wf}$ are initial and final weights $(\mathrm{g})$ and $\mathrm{t}$ is the time of experiment (days), Weight Specific growth rate $(\mathrm{WSGR})=100(\operatorname{lnWf}-\ln \mathrm{Wi}) / \mathrm{t}$, where $\mathrm{Wi}$ and $\mathrm{Wf}$ are initial and final weights $(\mathrm{g})$ and $\mathrm{t}$ is the time of experiment (days), Weight gain $\%$ (WG \%) =WG/ Wi x 100, where Wi is initial weight and WG is weight gain (g).

The physiology effects of European seabass (D. labrax) fry sources (wild and two hatcheries) on condition factor of total and standard length growth, hepatosomatic and vesrosomatic indexes. The NIOF marine hatchery produced fry achieved the best significant $(\mathrm{P}<0.05)$ results in all this physiology parameters. Hebalah [27] found that Length-weight relationship gives an indication of the degree of the well-being of farm fish than that inhabit in El-Maadyia region. The condition factor is used in order to compare the condition, fatness or wellbeing of fish. It is based on the hypothesis that heavier fish of a particular length are in a better physiological condition [28]. Condition factor is also a useful index for monitoring of feeding intensity, age, and growth rates in fish [29]. It is strongly influenced by both biotic and abiotic environmental conditions and can be used as an index to assess the status of the aquatic ecosystem in which fish live [30]. Hebalah [27] showed that the results revealed that the mean value of condition factor for seabass from fish farm was higher than that captured from ElMaadyia region. Also, it may be attributed to fish farm do not suffer the deficiency of food. Also, it was obvious significant differences in the mean values of condition factor for different seasons of Seabass collected from El-Maadyia region, while fish farm showed no seasonal significant differences in the mean values of condition factor. Hebalah [27] reported that fishery research is necessary to understand the many 
complex factors that contribute to the health and decline of our resources. This research is needed to provide management with guidance in making decisions to ensure sustainable fisheries. These research protocols must describe past and ongoing monitoring of the fishery. Little biological information on European seabass in Egyptian Mediterranean water has been gathered in the past years. Hebalah [27] reported that hepato-somatic index (HSI) has been used in fishery biology as a useful tool for assessing the fish condition.

Facey [31] stated that H.S.I. as a biomarker is often correlated with exposure to various contaminants (e.g., polychlorinated biphenyls, polycyclic aromatic hydrocarbons, and some heavy metals). Exposure to contaminants can lead to an increase in liver size as a result of increase in hepatocytes size (hypertrophy) or number (hyperplasia) [32]. Heath [33] and Facey [34] studies evaluating the relative liver size of fishes from contaminated and reference sites often utilize the HSI. Goede [35] and Ahmed [36] have used HSI as a biomarker of contaminant exposure. Hebalah [27] showed that the highest values of Hepato-somatic index for seabass from fish farm than that captured from El-Maadyia region can be attributed to feed on artificial food in aquaculture comparing with natural food organism for fish from El-Maadyia region. Rajaguru [37] reported that the lowest values of hepatosomatic indices were recorded only during the peak spawning period. This is in agreement with Hebalah [27] finding in El-Maadyia region, where the lowest values of hepatosomatic indices were found in spawning season (spring to summer).

The European seabass (D. labrax) fry sources (wild and two hatcheries) water quality parameters, Temperature in ${ }^{\circ} \mathrm{C}, \mathrm{pH}$ : Acidity and alkalinity parameter, Dissolved oxygen $\%$, conductivity in Ms/cm, TDS: Total dissolved solids in part per million and salinity in ppt: part per thousand (Table 3.). The wild collected fry achieved the best significant $(\mathrm{P}<0.05)$ results in all this water quality parameters. Hebalah [27] showed that the water quality of European seabass (D. labrax) collecting seasons and locations recorded that El-Maadyia region in the summer season had the best significant $(\mathrm{P}<0.05) \mathrm{DO} \%$ results compared with other location and other seasons. The fish farm in the summer season had the highest significant $(\mathrm{P}<0.05) \mathrm{pH}$ results compared with other location and other seasons. El-Maadyia region in the spring and winter seasons had the highest significant $(\mathrm{P}<0.05)$ TDS results compared with other location and other seasons. El-Maadyia region in the spring, summer and autumn seasons had the highest significant $(\mathrm{P}<0.05)$ salinity results compared with other location and other seasons. El-Maadyia region in the winter season had the best significant $(\mathrm{P}<$ $0.05)$ EC results compared with other location and other seasons. El-Maadyia region in the summer season and the fish farm in the winter season had the best significant $(\mathrm{P}<0.05)$ turbidity results compared with other location and other seasons. Hebalah [13] recorded that European seabass (D. labrax) newly hatched larvae tanks water quality showed mostly no significant $(\mathrm{P}<0.05)$ differences between treatments results within the optimum water quality ranges for European seabass larval rearing. Also Hebalah [13] recorded that European seabass (D. labrax) post larvae tanks water quality showed mostly no significant $(\mathrm{P}<0.05)$ differences between treatments results within the optimum water quality ranges for European seabass post larval rearing.

These results in agreement with Hebalah [3] and Salem $[5,12]$ results that indicated European Seabass eggs, yolk sac larvae and first fed larvae to weaning tanks water quality results performances were within suitable limits for Seabass, also in agreement with Zaki [38], Nour [17] and EFSA [39] whom reported that the optimum European seabass eggs incubator water temperature is in the range of $12-15^{\circ} \mathrm{C}$, salinity $32-40 \mathrm{ppt}$, oxygen concentration $7.0-8.0 \mathrm{mg} \mathrm{l}^{-1}$, oxygen saturation 80 $100 \%$ and $\mathrm{pH} 7.9-8.1$. Yeong [40] indicated that water quality monitoring showed no statistically significant differences between different diets, and the observed values indicate that none of the experimental diets affected the quality of water and culture water parameters were within the suitable range. Sonu [41] reported that the effects of beneficial bacteria in an aquaculture system can be explained by various mechanisms such as improvement of water quality, antagonism towards pathogens including competition for adhesion sites, enzymatic contribution to digestion in the host, and stimulation of the host immune response [42]. Grati [43] reported that although sea bass is known as a euryhaline species, and alterations in metabolic rate with varying salinity seem to be small [44], post larvae usually aggregate in brackish waters of shallow tidal lagoons and estuaries [44, 45] and then migrate offshore as they grow [46]. Environmental variables, such as water temperature, salinity, and oxygen

Egypt. J. Vet. Sci. Vol. 49, No.1 (2018) 
concentration, are reported as driving factors which may govern the behavioral processes that determine spatial and temporal distribution pattern of this species [44]. The difference of temperature between the reef site and inshore areas was negligible (around $1-2{ }^{\circ} \mathrm{C}$ ). Oxygen concentration was very high everywhere (110$120 \%$ saturation), due to the frequent mixing of the water column [43]. Therefore, the main factor for leaving the artificial reef was likely the salinity which, in the north-western Adriatic coast, gradually increases with the distance from the shoreline and, hence, with depth, as a consequence of the great rivers' inflow [47]. In fact, sea bass aggregated around river mouths where the salinity was similar to that observed in the fish farms and lower than that observed at the release site. Other possible factors that could have contributed to the sea bass' inshore migration could be either a greater availability of more suitable prey items in shallow waters, and/or the occurrence of predators (Conger conger) at the reef site. In fact, experiments carried out on hatchery-reared individuals obtained from the same broodstock used in this study showed that the young sea bass had fully developed antipredator responses, even though they displayed a lower reactivity to predators in respect to wild juveniles [48]. According to other studies [44, 45, 46], a positive relationship was found between the size of recaptured sea bass and depth, showing that, as fish grew, they gradually migrated towards greater depths aggregating around man-made structures, such as artificial reefs and mussel cultures. Breakwaters and harbors seemed to be particularly suitable habitat for sea bass up to an individual weight of about 250 g. A similar behavior was observed during UVC on the local wild population of sea bass. In fact, dense schools of small sea bass (individual weight around $20 \mathrm{~g}$ ) were observed in shallow waters $(2-3 \mathrm{~m})$, while large specimens (from 0.5 to $5 \mathrm{~kg}$ ) were found around artificial reefs and mussel cultures at depths ranging from 10 to $15 \mathrm{~m}$. Fifteen-eighteen meters depth is, indeed, the external limit of the spatial distribution of D. labrax in the area as also confirmed by its absence in the catches obtained more offshore by either professional (bottom and pelagic trawlers) and recreational fishermen as well as during research fishing surveys [43].

TABLE 3. Water and bacterial quality of wild collected and hatcheries produced European seabass (D. labrax) fry.

\begin{tabular}{|c|c|c|c|}
\hline Treatments & Wild & GAFRD K21 & NIOF \\
\hline \multirow{2}{*}{ Temp } & 24.80 & 24.35 & 24.65 \\
\hline & \pm 0.14 & \pm 0.07 & \pm 0.21 \\
\hline \multirow{2}{*}{ pH } & $8.03^{\mathrm{b}}$ & $8.20^{\mathrm{a}}$ & $8.24^{\mathrm{a}}$ \\
\hline & \pm 0.08 & \pm 0.01 & \pm 0.04 \\
\hline \multirow{2}{*}{ DO\% } & $109.60^{\mathrm{a}}$ & $100.35^{b}$ & $94.75^{\mathrm{c}}$ \\
\hline & \pm 0.99 & \pm 0.78 & \pm 1.20 \\
\hline \multirow{2}{*}{ Ec } & 54.86 & 94.85 & 188.10 \\
\hline & \pm 13.44 & \pm 119.57 & \pm 0.28 \\
\hline \multirow{2}{*}{ TDS } & $31.59^{b}$ & $120.50^{\mathrm{a}}$ & $120.75^{\mathrm{a}}$ \\
\hline & \pm 3.54 & \pm 0.28 & \pm 0.78 \\
\hline \multirow{2}{*}{ Salinity } & $6.50^{\mathrm{c}}$ & $34.85^{b}$ & $36.80^{\mathrm{a}}$ \\
\hline & \pm 0.71 & \pm 0.07 & \pm 0.14 \\
\hline \multirow{2}{*}{ VBCF (CFU) } & $31.33^{\mathrm{a}}$ & $20.33^{b}$ & $3.00^{\mathrm{c}}$ \\
\hline & \pm 3.21 & \pm 1.53 & \pm 1.00 \\
\hline \multirow{2}{*}{ BBCF (CFU) } & $1.00^{\mathrm{b}}$ & $2.33^{\mathrm{ab}}$ & $3.00^{\mathrm{a}}$ \\
\hline & \pm 1.00 & \pm 0.58 & \pm 1.00 \\
\hline \multirow{2}{*}{ BBCW (CFU) } & $0.00^{\mathrm{b}}$ & $4.00^{\mathrm{a}}$ & $3.67^{\mathrm{a}}$ \\
\hline & \pm 0.00 & \pm 1.00 & \pm 1.53 \\
\hline
\end{tabular}

Values in the same row within the subtales with different letters are significantly different at $P=0.05$.

Temp: Temperature in ${ }^{\circ} \mathrm{C}, \mathrm{pH}$ : Aciditiy and alkalinity parameter, DO\%: Dissolved oxygen $\%, \mathrm{EC}$ : conductivity in $\mathrm{Ms} / \mathrm{cm}$, TDS: Total dissolved solids in part per million, Salinity: Salinity in part per thousand, CFU: Colony forming unit, F: Fry, W: Water, VBC: Vibrio sp. bacterial count in CFU/ml, BBC: Bacillus sp. bacterial count in CFU/ml. 
European seabass (D. labrax) fry sources (wild and two hatcheries) effects on water and fry Vibrio sp. and Bacillus sp. bacterial counts (Table 3.). Vibrio sp. hadn't detected in the water source sample of the three fry sources. The wild collected fry achieved the best significant $(\mathrm{P}<$ 0.05 ) water and fry results in Bacillus bacterial counts. Salem [12, 3, 5] recorded that rotifers and artemia enrichment and yolk sac larvae and first fed larvae to weaning tanks bacterial counts of the potentially pathogenic bacteria such as Aeromonas sp., Staphylococcus sp. and Vibrio sp., or as potentially useful bacteria such as Bacillus $s p$ and total bacterial count in the treatments showed that the potentially pathogenic bacteria reduced by GMW+MP followed by GMW+S than GMW and FMW. In 2013, Egypt mass mortalities in Kafr El-Sheik and El- Behira governorates tilapia fish farms which diagnosed as A. hydrophilla outbreak and also, in Maryut Valley, Alexandria governorate in European seabass, gilthead seabream and meagre farms but with different reasons of high temperatures and low oxygen stress in seabass and meagre, 100 tons equals 7 million L. E. loses [5] and because of Vibrio sp. outbreak in gilthead seabream after seabass and seabream wild collected fry were transported to this farms [5].

\section{Conclusion}

Egypt marine fish farmers prefer wild collected European seabass (D. labrax) fry than hatchery produced fry. Marine hatcheries need more efforts and technology transfer to help marine aquaculture and fisheries development, that need ranching and restocking with hatchery high quality produced fry to convince farmers that hatchery produced fry is better not only because wild fry would transfer pathogens causing outbreaks but also due to hatchery fry better growth and quality.

Acknowledgment: The authors would like to thank NIOF and GAFRD marine hatcheries teams and mangers for their help and support. Also, the authors would like to thank Dr. Hassan Ibrahim and Dr. Ahmed Abu El-Wafa, Marine Microbiology Lab., NIOF for their help in fry and water microbiology.

Funding statements: The authors declare that this work is authors self-funded and it's a part of Mohamed Abokadah going M. Sc thesis.

Conflicts of interest: The authors declare that there are no conflict of interest.

Egypt. J. Vet. Sci. Vol. 49, No.1 (2018)

\section{References}

1. FAO.The state of world fisheries and aquaculture. Rome, FAO. 204 p., (2016).

2. GAFRD, General authority for fish resources development. Fish statistics book. 107p. (2017).

3. Salem, Ahmed Md. Marine probiotic and synbiotic for Egypt marine hatcheries development. Book. Scholars Press Academic Publishing, ISBN13:978-3-639-66189-7., p. 244. (2014).

4. Salem, A. M., Ibrahim, H. A., Effects of Egypt first marine synbiotic supplemented and/or fermented microdiets on the European Seabass larvae length growth and physiology. Presented in ontogeny and early rearing husbandry session and published on the Aquaculture Europe 2017 held in Dubrovnik, Croatia on October, 17-20, 2017 conference book, pp. 1022- 1023. (2017).

5. Salem, Ahmed Md., Nour, A. M., Srour, T. M., Assem, S. S., Ibrahim, H. A., El-Sayed, H. S. Greenwater, marine Bacillus subtilis HS1 probiotic and synbiotic enriched artemia and rotifers improved European Seabass Dicentrarchus labrax larvae early weaning length growth, survival, water and bacteriology quality. American Journal of Life Sciences. Special Issue: New Horizons in Basic and Applied Zoological Research, 3 (61), 45-52. doi: 10.11648/j.ajls.s.2015030601.17. (2015).

6. FAO, Food and agriculture organization of the United Nations. Fezzardi, D., Massa, F., ÀvilaZaragoza, P., Rad, F., Yücel-Gier, G., Deniz, H., Hadj Ali Salem, M., Hamza, H. A., Ben Salem, S. Indicators for sustainable aquaculture in Mediterranean and Black Sea countries. Guide for the use of indicators to monitor sustainable development of aquaculture. Studies and Reviews. General Fisheries Commission for the Mediterranean. No 93. Rome, FAO., 60 pp. (2013).

7. FAO, Food and Agriculture Organizations of the United Nations, FAO Yearbook of Fishery Statistics, Rome, vol. 90. (2002).

8. FAO, Food and Agriculture Organization of the United Nations, Yearbook of Fishery Statistics, Rome, Vol. 94. (2004).

9. GAFRD, General authority for fish resources development. Fish statistics book.106p. (2010).

10. Sadek, S., Mires, D. Capture of the wild finfish fry in Mediterranean coastal areas and possible impact on aquaculture development and marine genetic resources. Israeli Journal of Aquaculture Bamidgeh, 52 (2), 77-88. (2000). 
11. Abdel-Kader, W. N. Effect of environmental changes on the biological characteristics of some important mullets species in Egypt. Ph. D thesis in agricultural sciences (fish production), animal and fish production department, faculty of agriculture (saba basha), Alexandria university, Alexandria, Egypt, 154p. (2017).

12. Salem and Ahmed Md. Marine fish reproduction and larvae rearing development using probiotic. $\mathrm{Ph}$. $\mathrm{D}$ thesis in agricultural sciences (fish production), animal and fish production department, faculty of agriculture (saba basha), Alexandria university, Alexandria, Egypt, 173p. (2013).

13. Hebalah, Shaimaa M. Effect of dietary vegetable oil on the growth of marine cultured fish. Ph. D thesis in agricultural sciences (fish production), animal and fish production department, faculty of agriculture (saba basha), Alexandria university, Alexandria, Egypt, 148p. (2015a).

14. Castell, J. D., Tiews, K. (Eds.) Report of the EIFAC, IUNS and ICES Working Group on the standardization of methodology in fish nutrition research. Humberg, Federal Republic of Germany, 21-23 March, 1979. EIFAC Tech. Pap., 36, 24 pp. (1980).

15. Yildiz, M., Şener, E., Timur, M. Effects of variations in feed and seasonal changes on body proximate composition of wild and cultured sea bass (Dicentrarchus labrax L.). Turkish Journal of Fisheries and Aquatic Sciences, 7, 45-51. (2007).

16. Garber, M.J., De Yonge, K.G., Byatt, J.C., Lellis, W.A., Honey field, D.C., Bull, R.C., Schelling, G.T., Roeder, R.A. Dose response effects of recombinant bovine somatotropin (Posilac TM) on growth performance and body composition of two-year-old rainbow trout (Oncorhynchus mykiss). Journal of Animal Science, 73, 32163222, (1995).

17. Nour, A.A., Zaki, M.A., AbdEl-Rahim, M.M., Mabrouk, H.A. Factors affecting swim-bladder inflation, survival and growth performance of gilthead seabream Sparus aurata larvae: 2- water salinity. Egyptian J. of Aquatic Research, 30, 418428, (2004).

18. Zobell, C. E. Marine Microbiology. Waltham, MA: Chronica Botanica., 240 pp.

19. Kobayashi, T., Enomato, S., Sakazaki, R., Kuwahara, S. A new selective medium for pathogenic Vibrios. TCBS agar (modified Nakanishi's agar). Japanese. J. Bacteriol., 18, 387-391, (1963).
20. Duncan, D. B. Multiple range and multiple F-tests. Biometrics, 11, 1-42 (1955).

21. StatSoft, Inc. STATISTICA for windows [Computer program manual]. Tulsa, OK: StatSoft, Inc., 2300 East 14th Street, website: http://www. statsoft.com. (1995).

22. Lagler, K. F., Baradach, J. E., Miller, R. R. Ichthyology. In: Growth of fishes. John Wiley \&Sons, New York, London, Sydney, 163-168 (1977).

23. Ndimele, P. E., Kumolu- Johnson, C. A., Aladetohun, N. F., Ayorinde, O. A. Lengthweight relationship, condition factor and dietary composition of Sarotherodon melanotheron, Ruppell, 1852 (Pisces: cichlidae) in Ologe Lagoon, Lagos, Nigeria, Agriculture and Biology Journal of North America, 1(4): 584-590 (2010).

24. Kumolu-Johnson, C. A., Ndimele, P. E. Lengthweight relationships of nine fish species from Ologe Lagoon, Lagos, Nigeria, African Journal of Biotechnology, 10 (2), 241-243 (2011).

25. Ariğ, N., Süzer, C., Gökvardar, A., Başaran, F., Çoban, D., Yildirim, Ş., Kamaci, O., Firat, K., Saka, Ş. Effects of probiotic (Bacillus sp.) supplementation during larval development of gilthead sea bream (Sparus aurata, L.). Turkish Journal of Fisheries and Aquatic Sciences, 13, 407-414. (2013).

26. El-Dakar, A. Y., Shalaby, S. M., Saoud, I. P. Assessing the use of a dietary probiotic/ prebiotic as an enhancer of spinefoot rabbitfish Siganus rivulatus survival and growth. Aquac. Nutr., 13, 407-412. (2007)

27. Hebalah, M. M. Effect of environmental conditions and physiological changes on sea bass (Dicentrarchus labarx). Ph. D thesis in agricultural sciences (fish production), animal and fish production department, faculty of agriculture (saba basha), Alexandria university, Alexandria, Egypt, 162p. (2015b).

28. Bagenal, T. B., Tesch, F. W. Age and growth. In: Bagenal, T. (Ed.), Methods of Assessment of Fish Production in Fresh Waters. Oxford Blackwell Scientific Publication, pp.: 101-136 (1978).

29. Oni, S. K., Olayemi, J. Y., Adegboye, J. D. Comparative physiology of three ecologically distinct fresh water fishes, Alestes nurse (Ruppell), Synodontis schall (Bloch), S. schneider and Tilapia zilli (Gervais), J. Fish Biol., 22, 105-109 (1983).

30. Anene, A. Condition factors of four cichlid species of a man-made lake in Imo state, Southeast, Nigeria, Turk. J. Fish. Aquat. Sci., 5, 43-47. (2005). 
31. Facey, D. E., Blazer, V. S., Gasper, M. M., Turcotte, C. L. Using Fish Biomarkers to Monitor Improvements in Environmental Quality. Journal of Aquatic Animal Health, 17, 263-266. (2005).

32. Hinton, D. E., Lauren. D. J. Liver structural alterations accompanying chronic toxicity in fishes: potential biomarkers of exposure, in: McCarthy, J. F., Shugart, L. R., (Eds.), Biomarkers of environmental contamination. CRC Press, Boca Raton, Florida, pp.17-57. (1990).

33. Heath, A. G. Water Pollution and Fish. Physiology. CRC Press. Inc. Florida. 245 p. (1990)

34. Facey, D. E., Leclerc, C., Dunbar, D., Arruda, D., Pyzocha, L., Blazer, V. Physiological indicators of stress among fishes from contaminated areas of Lake Champlain. in Manley, T.O., Manley, P.L., (Ed.), Lake Champlain in transition: from research toward restoration-water science and application, 1 . American Geophysical Union, Washington, D.C., pp. 349-359. (1999).

35. Goede, R.W., Barton, B.A. Organismic indices and an autopsy-based assessment as indicators of health and condition of fish, in: Adams, S.M., (Ed.), Biological indicators of stress in fish. American Fisheries Society, Symposium 8, Bethesda, Maryland, pp. 93-108. (1990).

36. Ahmed, M.A.S., Shakweer, L.M., Hemaida, H.A. , Alsayes, A.A. Monitoring of some heavy metals and wellbeing status of some fish species from middle Alexandria and Sidi-Barany areas Mediterranean coast, Egypt. Egyptian Journal of Aquatic Research, 37 (2). (2011).

37. Rajaguru, A. Biology of two co-occurring tonguefishes, Cynoglossus arel and C. lida (Pleuronectiformes: Cynoglossidae), from Porto Nova, southeast coast of India. Fishery Bulletin, 90, 328-367. (1992).

38. Zaki, M. A., Nour, A. A., AbdEl-Rahim, M. M., Mabrouk, H. A. Factors affecting swim-bladder inflation, survival and growth performance of gilthead seabream Sparus aurata larvae: (1) rotifers Brachionus plicatilis consumption. Egyptian J. of Aquatic Research, 30, 406- 417. (2004).

39. EFSA, European Food Safety Authority. Animal Welfare Aspects of Husbandry Systems for Farmed European seabass and gilthead seabream. Scientific report of EFSA prepared by Working Group on seabass/seabream welfare. Annex I to The EFSA Journal, 844, 1-89 (2008).

40. Yeong, Y. S. Protection of Artemia from vibriosis by heat shock and heat shock proteins. $\mathrm{PhD}$ thesis, Ghent University, Belgium. 190p. (2008).
41. Sonu, Babbar, B. K., Sehgal, G. K. Sehgal, H. S., Kondal, J. K. Effects of dietary fish oil substitution with sunflower oil on the survival, growth performance and proximate composition of Cyprinus carpio. International Journal of Advanced Research, 2, 8, 737-742 (2014).

42. Farzanfar, A. The use of probiotics in shrimp aquaculture. FEMS Immunol. Med. Microbiol., 48,149-158 (2006).

43. Grati, F., Scarcella, G., Bolognini, B., Fabi, G. Releasing of the European sea bass Dicentrarchus labrax (Linnaeus) in the Adriatic Sea: Large-volume versus intensively cultured juveniles. Journal of Experimental Marine Biology and Ecology, 397, 144-152 (2011).

44. Claireaux, G., Lagardère, J. P. Influence of temperature, oxygen and salinity on the metabolism of the European sea bass. J. Sea Res., 42, 157-168 (1999).

45. Reynolds, W. J., Lancaster, J. E., Pawson, M. G. Patterns of spawning and recruitment of sea bass to Bristol Channel nurseries in relation to the 1996 "Sea Empress" oil spill. J. Mar. Biol. Ass. UK, 83, 1163-1170 (2003).

46. Pawson, M. G., Pickett, G. D., Leballeur, J., Brown, M., Fritsch, M. Migrations, fishery interactions, and management units of sea bass (Dicentrarchus labrax) in Northwest Europe. ICES J. Mar. Sci., 64, 332-345 (2007).

47. Campanelli, A., Fornasiero, P., Marini, M. Physical and chemical characterization of water column in the Piceno coastal area (Adriatic Sea). Fresenius Environmental Bulletin, 13, 430-435. (2004).

48. Malavasi, S., Georgalas, V., Lugli, M., Torricelli, P., Mainardi, D. Differences in the pattern of antipredator behaviour between hatchery-reared and wild European sea bass juveniles. J. Fish Biol., 65 (Suppl. A), 143155 (2004).

(Received 31/12/2017; accepted 30/1/2018) 


$$
\begin{aligned}
& \text { تأثير مصدر زريعة أسمالك القاروص على أداء النمو والفسيولوجي } \\
& \text { أحمد محمد محمد علي سالم* ، ناجي منصور البرماوي*** ، نادر رجب عبد السلام*** و محمد صبحي }
\end{aligned}
$$

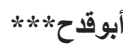

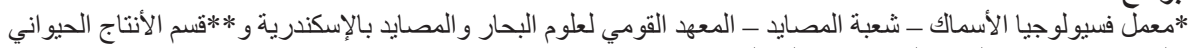

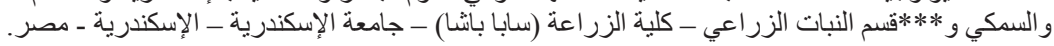

تهدف هذة الدر اسة الى تقييم تأثير المصادر المختلفة لزريعة اسماك القاروص الأوروبى علي أداء النمو والأداء

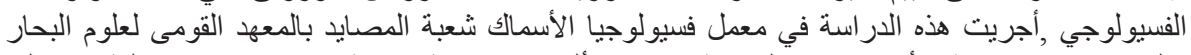

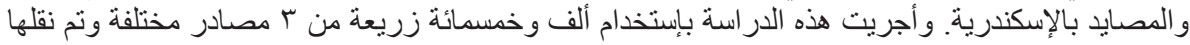

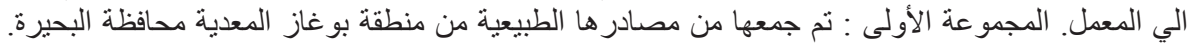

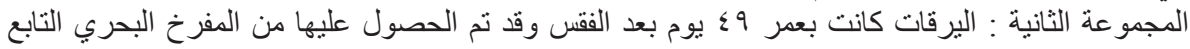

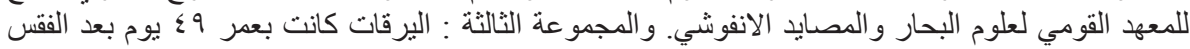

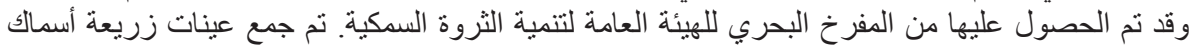

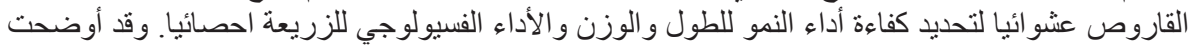

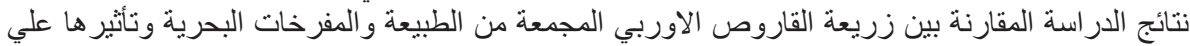

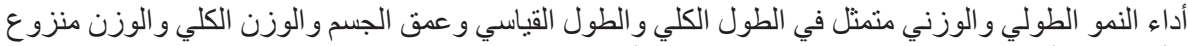

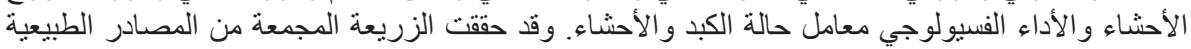

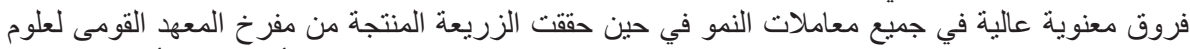

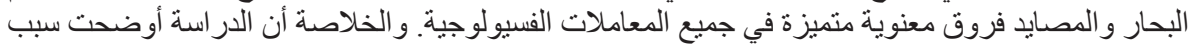

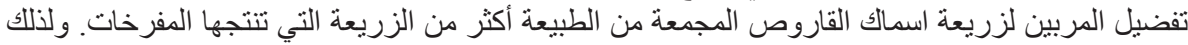



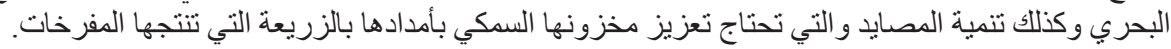
الكلمات الدالة: القاروص الأوروبى ,الزريعة, الطبيعة, المفرخ, النمو, معامل حالة الكبد ومعامل حالة الأحشاء. 